\title{
A NEW SPECIES, TRICHOSPORON DOMESTICUM, ISOLATED FROM THE HOUSE OF A SUMMER-TYPE HYPERSENSITIVITY PNEUMONITIS PATIENT IN JAPAN
}

\author{
TAKASHI SUGITA, AKEMI NISHIKAWA, TAKAKO SHINODA,* \\ KAZUKO YOSHIDA, ${ }^{1}$ AND MASAYUKI ANDO ${ }^{1}$ \\ Department of Microbiology, Meiji College of Pharmacy, Tanashi 188, Japan \\ ${ }^{1}$ First Department of Internal Medicine, Kumamoto University Medical School, \\ Kumamoto 860, Japan
}

(Received June 12, 1995; Accepted August 16, 1995)

\begin{abstract}
A new species, Trichosporon domesticum Sugita, Nishikawa et Shinoda, is proposed for a strain isolated from the house of a summer-type hypersensitivity pneumonitis patient in Kumamoto, Japan. The nuclear DNA of $T$. domesticum showed intermediate relatedness to that of T. montevideense; however, their genome sizes were significantly different. These findings suggest that they represent separate species. $T$. domesticum is distinguished from $T$. montevideense by its inability to assimilate Darabinose, ribitol, and dulcitol. The type strain of $T$. domesticum is strain M 9401, which has been deposited in the Japan Collection of Microorganisms as JCM 9580.
\end{abstract}

Trichosporon Behrend 1890 is a genus of basidiomycetous yeasts, having septated mycelia, pseudomycelia and arthroconidia (8). Recently, Guého et al. (6) revised the genus Trichosporon on the basis of morphological and biochemical properties, nuclear DNA relatedness and 26S ribosomal RNA partial sequence analyses. Later, Sugita et al. (18) reclassified T. cutaneum and its synonyms by nuclear DNA relatedness and proposed a new classification. Trichosporon is a medically important genus which contains the causative agents of white piedra and trichosporonosis (5). In addition, Ando and his coworkers $(2,3,14,16,21,22)$ suggested that $T$. cutaneum is the causative agent of summer-type hypersensitivity pneumonitis (SHP) in Japan. During isolation of yeasts from an SHP patient's house, we recovered a strain that is taxonomically closely related to $T$. montevideense (Aciole de Queiroz) Guého \& M. Th. Smith. A new species, T. domesticum Sugita, Nishikawa et Shinoda, is proposed for the yeast.

* Address reprint requests to: Dr. Takako Shinoda, Department of Microbiology, Meiji College of Pharmacy, 1-22-1 Yato-cho, Tanashi 188, Japan. 


\section{MATERIALS AND METHODS}

Yeast strain. Strain M 9401 (type strain) was isolated from a damp and rotten wooden sideboard in the kitchen of an SHP patient's house in September 1985 in Kumamoto, Japan. The organism was obtained by swabbing with a cotton applicator (Transwab Medical Wire and Equipment, Wilshire, U.K.) and then was recovered from three kinds of Sabouraud agar plates: agar plates containing $20 \mathrm{U}$ of penicillin per milliliter, or $40 \mu \mathrm{g}$ of streptomycin per milliliter and an antibiotic-free plate. Trichosporon montevideense and $T$. brassicae were used for taxonomic comparisons (Table 1).

Physiological, biochemical and morphological characteristics. Physiological and biochemical characteristics were investigated by the method of van der Walt and Yarrow (19). Colonies grown on YM agar plates (Difco Laboratories, Detroit, MI, U.S.A.) at $27^{\circ} \mathrm{C}$ for 14 days were examined morphologically. Microscopic morphology was determined from slide cultures on cornmeal agar and from YM broth cultures, both incubated at $27^{\circ} \mathrm{C}$ for 3 days. Growth at 20,27 and $37^{\circ} \mathrm{C}$ was determined on YM agar.

Ubiquinone system. Ubiquinone isoprenologues were extracted and purified as described by Yamada and Kondo (20). The ubiquinone system was identified by high-performance liquid chromatography (HPLC) by comparing the retention time with those of standard ubiquinones. HPLC was performed with an LC-9A Liquid Chromatograph and an SPD-2A spectrometric detector (Shimadzu, Kyoto, Japan) with a column $(4.6 \mathrm{~mm}$ I.D. by $25 \mathrm{~cm}$ ) of Zorbax ODS (Du Pont Co., Wilmington, DE, U.S.A). The ubiquinone was eluted with an ethanol- $\mathrm{H}_{2} \mathrm{O}(97: 3$, $\mathrm{v} / \mathrm{v}$ ) mobile phase at a flow rate of $1.0 \mathrm{ml} / \mathrm{min}$ and was detected at $285 \mathrm{~nm}$.

DNA isolation and purification. Nuclear DNA was isolated by the method of Restrepo and Barbour (15) with some modification as described by Sugita et al. (18). Nuclear DNA was purified with hydroxyapatite (Bio-Rad Laboratories,

Table 1. Strains used and their coenzyme Q systems and sources.

\begin{tabular}{|c|c|c|c|}
\hline Species & Strain $^{a}$ & $\begin{array}{l}\text { Ubiquinone } \\
\text { system }\end{array}$ & Source \\
\hline $\begin{array}{l}\text { Trichosporon domesticum Sugita, } \\
\text { Nishikawa et Shinoda }\end{array}$ & M $9401^{\mathrm{T}}$ & Q9 & $\begin{array}{l}\text { Damp and rotten wooden } \\
\text { sideboard in a kitchen }\end{array}$ \\
\hline $\begin{array}{l}\text { Trichosporon montevideense } \\
\quad \text { (Aciole de Queiroz) Guého et Smith }\end{array}$ & CBS $6721^{\mathrm{T}}$ & $\mathrm{Q}^{b}$ & Water purification tank \\
\hline $\begin{array}{l}\text { Trichosporon montevideense } \\
\text { (Aciole de Queiroz) Guého et Smith }\end{array}$ & CBS 8261 & Q9 & Human faeces \\
\hline Trichosporon brassicae Nakase & CBS $6382^{\mathrm{T}}$ & $\mathrm{Q}^{b}$ & Cabbage \\
\hline
\end{tabular}

a M, Meiji College of Pharmacy, Tokyo, Japan; CBS, Centraalbureau voor Schimmelcultures, Baarn, The Netherlands.

${ }^{b}$ Guého et al. (6).

$\mathrm{T}$, type strain. 
Richmond, CA, U.S.A.) by a batch method (11). The quality of the purified nuclear DNA was determined from thermal profiles.

DNA base composition. Nuclear DNA base composition was determined by nucleotide separation by HPLC after nuclear DNA digestion with Nuclease P1 (Yamasa Shoyu, Chiba, Japan) as described by Sugita et al. (18).

DNA reassociation by chemiluminescence. Nuclear DNA-DNA hybridization was determined by the method of Adnan et al. (1) in the manner we described previously (18). The nuclear DNA-DNA hybridization reaction involved annealing of biotin-labeled nuclear DNA to nuclear DNA that had been covalently bound to wells in a microplate. The plate was examined for chemiluminescence with a Luminous CT-9000 (DIA-IATRON, Tokyo, Japan) after incubation with LumiPhos 530 (Wako Pure Chemical Industries Ltd., Osaka, Japan). Escherichia coli JH nuclear DNA was used as a negative control.

DNA reassociation by spectroscopy. Reassociation was performed with a model 2600 Spectrophotometer equipped with a model 2527 Thermoprogrammer (Gilford Instruments Inc., Oberlin, OH, U.S.A.). Sheared nuclear DNA was dialyzed against $5 \times$ SSC (SSC: $0.15 \mathrm{M} \mathrm{NaCl}, 0.015 \mathrm{M}$ citric acid, $\mathrm{pH} 7.0$ ) containing $20 \%$ dimethylsulfoxide. The nuclear DNA concentration of the sample was adjusted to $75 \mu \mathrm{g} / \mathrm{ml}\left(A_{260}=1.5\right)$. After the nuclear DNA sample was denatured to single strand at $T_{\mathrm{m}}+10^{\circ} \mathrm{C}$, the temperature was reduced to $T_{\mathrm{m}}-25^{\circ} \mathrm{C}$, where it was maintained. Estimates of relative genome size were determined by comparisons of $C_{\mathrm{o}} t_{0.5}$ values $\left(C_{\mathrm{o}} t=\right.$ initial nucleotide concentration in moles per liter $\times$ time in seconds) obtained from reassociation kinetics.

\section{RESULTS AND DISCUSSION}

Trichosporon domesticum Sugita, Nishikawa et Shinoda, sp. nov.

In liquido "YM" post dies 3 ad $27^{\circ} \mathrm{C}$, cellulae ellipsoideae aut ovoideae, 3.7$4.8 \times 5.2-12.8 \mu \mathrm{m}$. In agaro "YM" post dies 14 ad $27^{\circ} \mathrm{C}$, cultura in striis flavida, rugosa, madida, margine undulata. Arthroconidia formantur. Fermentatio nulla. Glucosum, galactosum, L-sorbosum, sucrosum, maltosum, cellobiosum, trehalosum, lactosum, melezitosum, amylum solubile, inulinum, D-xylosum, L-arabinosum, D-ribosum, glycerolum, D-mannitolum, inositolum, D-sorbitolum (exiguum), ethanolum, DL-lacticum, acidum 2-ketogluconicum, acidum 5-ketogluconicum, acidum glucuronicum, $\mathrm{N}$-acetyl-glucosaminum, ( - )-acidum malicum, acidum succinicum (exiguum), acidum citricum, salicinum (exiguum), $\alpha$-methyl-Dglucosidum, glucono- $\delta$-lactonum et acidum D-glucosaminum assimilantur at non melibiosum, raffinosum, D-arabinosum, L-rhamnosum, erythritolum, ribitolum nec dulcitolum. Kalium nitricum, ethylaminum, cadaverinum et natrium nitrosum at non L-lysinum assimilantur. Diazonium caeruleum B positivum. Proportio molaris guanini + cytosini in acido deoxyribonucleico: 56.8 (per HPLC). Ubiquinonum majus: Q-9. Teleomorphosis ignota.

Holotypus: Isolata ex mensa putrida in culina, Kumamoto, Japan, 1985, JCM 
9580 (originaliter M 9401) conservatur in collectionibus culturarum quas "Japan Collection of Microorganisms," Wako, Saitama sustentat.

Growth in YM broth: After 3 days at $27^{\circ} \mathrm{C}$, the cells are ellipsoidal or long ovoidal, 3.7-4.8 $\times 5.2-12.8 \mu \mathrm{m}$ (Fig. 1A).

Growth on YM agar: After 14 days at $27^{\circ} \mathrm{C}$, the streak culture become yellowish, wrinkled all over the surface, moist and has an undulate margin.

Slide culture on corn meal agar: Arthroconidia are formed (Fig. 1B).

Fermentation:

$\begin{array}{llll}\text { Glucose } & - & \text { Lactose } & - \\ \text { Galactose } & - & \text { Trehalose } & - \\ \text { Sucrose } & - & \text { Melibiose } & - \\ \text { Maltose } & - & \text { Raffinose } & -\end{array}$

Assimilation of carbon compounds:

$\begin{array}{llll}\text { Glucose } & + & \text { Erythritol } & - \\ \text { Galactose } & + & \text { D-Mannitol } & + \\ \text { L-Sorbose } & + & \text { Inositol } & + \\ \text { Sucrose } & + & \text { D-Sorbitol } & + \text { (weak) } \\ \text { Maltose } & + & \text { Ribitol } & - \\ \text { Cellobiose } & + & \text { Ethanol } & + \\ \text { Trehalose } & + & \text { Dulcitol } & - \\ \text { Lactose } & + & \text { DL-Lactic acid } & + \\ \text { Melibiose } & - & \text { 2-Keto-gluconic acid } & + \\ \text { Raffinose } & - & \text { 5-Keto-gluconic acid } & + \\ \text { Melezitose } & + & \text { Glucuronic acid } & +\end{array}$

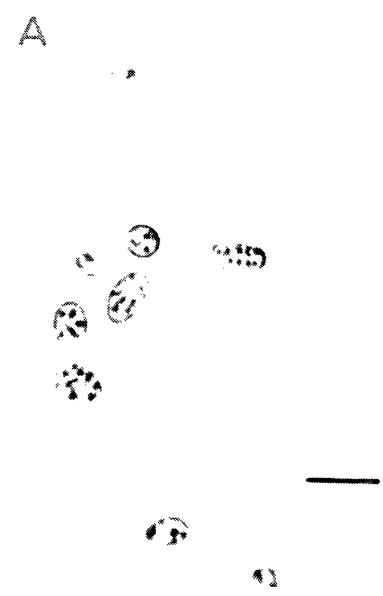

Fig. 1. Cell morphology of Trichosporon domesticum sp. nov.

(A) Vegetative cells of M9401 grown in YM broth for 3 days at $27^{\circ} \mathrm{C}$. (B) Arthroconidia of M 9401 that developed on cornmeal agar after 3 days incubation at $27^{\circ} \mathrm{C}$. Scale bar indicates $10 \mu \mathrm{m}$. 


$\begin{array}{lcll}\text { Soluble starch } & + & \text { N-Acetyl-glucosamine } & + \\ \text { Inulin } & + & (- \text { )-Malic acid } & + \\ \text { D-Xylose } & + & \text { Succinic acid } & + \text { (weak) } \\ \text { L-Arabinose } & + & \text { Citric acid } & + \\ \text { D-Arabinose } & - & \text { Salicin } & + \text { (weak) } \\ \text { D-Ribose } & + & \alpha \text {-Methyl-D-glucoside } & + \\ \text { L-Rhamnose } & - & \text { Glucono- } \delta \text {-lactone } & + \\ \text { Glycerol } & + & \text { D-Glucosamine } & +\end{array}$

Assimilation of nitrogen compounds:

Potassium nitrate

Sodium nitrite
L-Lysine hydrochloride $\quad+$

Cadaverine dihydrochloride +

Ethylamine hydrochloride +

Growth temperature: $20^{\circ} \mathrm{C}$, positive; $27^{\circ} \mathrm{C}$, positive; $37^{\circ} \mathrm{C}$, positive.

Cycloheximide resistance: $100 \mathrm{ppm}$, positive; $1,000 \mathrm{ppm}$, negative.

Diazonium blue B color reaction: Positive.

Splitting of arbutin: Positive.

Growth on $50 \%(w / w)$ glucose-yeast extract agar: Negative.

Growth in vitamin-free medium: Negative.

$\mathrm{G}+\mathrm{C}$ content of nuclear DNA: $56.8 \mathrm{~mol} \%$ (by HPLC).

Major ubiquinone system: Q-9.

Holotype strain: JCM 9580 (originally M 9401), isolated from a damp and rotten wooden sideboard in the kitchen of an SHP patient's house in Kumamoto, Japan in 1985 by Kazuko Yoshida. This strain has been deposited in The Japan Collection of Microorganisms, Wako, Saitama.

It has been suggested that T. cutaneum is one of the causative agents of SHP by Ando and his colleagues $(2,3,14,16,21,22)$. They have isolated Trichosporon species from an SHP patient's house in Japan $(2,3,16,22)$. We have already reported that Trichosporon species have several serotypes $(3,10,21)$. Our serological survey found that the serotype of $T$. domesticum was identical to those of $T$. montevideense and $T$. brassicae (unpublished data). On the other hand, Guého et al. (6) divided the genus Trichosporon into five major taxonomic groups based on 26S rRNA partial sequence analyses. Of the five groups, group 5 contains only two species, $T$. montevideense and $T$. brassicae. Nuclear DNA relatedness between the five groups was less than $34 \%(6,18)$. As stated above, we thought that our new species, $T$. domesticum might be taxonomically positioned in group 5 and compared it with the two species $T$. montevideense and $T$. brassicae. Three species, $T$. domesticum, $T$. montevideense and $T$. brassicae, have similar $\mathrm{G}+\mathrm{C}$ content of their nuclear DNA (Table 2). T. domesticum showed $56.8 \mathrm{~mol} \% \mathrm{G}+\mathrm{C}$ by the HPLC method. T. montevideense and T. brassicae ranged from 56.0 to $57.2 \mathrm{~mol} \%$. In nuclear DNA-DNA hybridization, $T$. domesticum exhibited very low nuclear DNA relatedness values, $0.3-17.2 \%$ to $T$. brassicae. However, the nuclear DNA of $T$. domesticum was shown to be intermediately related to that of the two strains of $T$. 
montevideense (46.9 and 61.2\%) (Table 2). Intermediate values such as our data have been reported infrequently. These values are generally regarded as representing a more differentiated strain within a species such as a variety or sibling species (7). In fact, we proposed that they should be reclassified as varieties in the same species but not as different species based on the limited nuclear DNA relatedness levels (40 to 56\%), although $T$. asahii, $T$. coremiforme and $T$. faecale, which belong to group 3, were described as different species by Guého et al. (6). Similar cases have been reported for the three varieties of Cryptococcus albidus (17) and the two varieties of Filobasidiella neoformans (4). On the other hand, Martini and Kurtzman (12) have reported that Saccharomyces pastorianus exhibits intermediate nuclear DNA relatedness to both $S$. cerevisiae and $S$. bayanus (58 and 70\%, respectively) even though these latter two species demonstrated $10 \%$ relatedness to each other. These observations, together with the genome sizes, led the authors to suggest that $S$. pastorianus is a partial amphidiploid which arose as a natural hybrid of $S$. cerevisiae and $S$. bayanus. Another example of apparent ploidy differences influencing speciation is to be found in comparisons of $S$. exiguus and its anamorph Candida holmii (9). The type strain $S$. exiguus and $C$. holmii show $76 \%$ nuclear DNA relatedness and have the same genome size. Other strains of each of the two species have a somewhat smaller genome despite relatively high relatedness with their respective type strains. These results were confirmed by electrophoretic karyotyping (13). From the above observations, it is important to demonstrate whether the genome is significantly larger or not. In the case of our new species, the observed $C_{\mathrm{o}} t_{0.5}$ values of $T$. domesticum and $T$. montevideense were 1.76 and 1.07 $\mathrm{mol} \cdot \mathrm{s} / l$, respectively (Table 3 ). Therefore, the genome size of $T$. domesticum is estimated to be approximately 1.6 times as large as that of $T$. montevideense. We speculate that the relatively high nuclear DNA relatedness between the two species is due to the difference in their genome sizes. Therefore, we propose $T$. domesticum as a new species, not a variety of $T$. montevideense, though their nuclear DNAs exhibit intermediate relatedness. Practically, $T$. domesticum is distinguished from T. montevideense by its inability to assimilate D-arabinose, ribitol and dulcitol, and

Table 2. Mol\% G $+\mathrm{C}$ of DNA and \% DNA relatedness among Trichosporon domesticum and related species.

\begin{tabular}{|c|c|c|c|c|c|}
\hline \multirow[b]{2}{*}{ Species } & \multirow[b]{2}{*}{ Strain } & \multirow{2}{*}{$\begin{array}{l}\mathrm{Mol} \% \\
\mathrm{G}+\mathrm{C}^{a}\end{array}$} & \multicolumn{3}{|c|}{$\%$ DNA relatedness with } \\
\hline & & & $\begin{array}{l}\text { T. domesticum } \\
\text { M } 9401^{\mathrm{T}}\end{array}$ & $\begin{array}{l}\text { T. montevideense } \\
\text { CBS } 6721^{\mathrm{T}}\end{array}$ & $\begin{array}{l}\text { T. montevideense } \\
\text { CBS } 8261\end{array}$ \\
\hline T. domesticum & $\mathrm{M} 9401^{\mathrm{T}}$ & $56.8 \pm 0.5$ & $100.0^{b}$ & & \\
\hline$T$. montevideense & CBS $6721^{\mathrm{T}}$ & $57.2 \pm 0.5$ & 61.2 & $100.0^{b}$ & \\
\hline$T$. montevideense & CBS 8261 & $57.0 \pm 0.4$ & 46.9 & 82.3 & $100.0^{b}$ \\
\hline T. brassicae & CBS $6382^{\mathrm{T}}$ & $56.0 \pm 0.4$ & 17.2 & 0.3 & 5.7 \\
\hline
\end{tabular}

a Mean \pm SD $(n=6)$.

b $100 \%$ related by definition.

$\mathrm{T}$, type strain. 
Table 3. $C_{0} t_{0.5}$ values of Trichosporon domesticum and T. montevideense.

\begin{tabular}{lll}
\hline & Strain & \multicolumn{1}{c}{$\begin{array}{c}\text { Observed } C_{\mathrm{o}} t_{0.5}{ }^{a} \\
(\mathrm{~mol} \cdot \mathrm{s} / l)\end{array}$} \\
\hline$T$. domesticum & $\mathrm{M} 9401^{\mathrm{T}}$ & $1.76 \pm 0.18$ \\
$T$. montevideense & $\mathrm{CBS} 6721^{\mathrm{T}}$ & $1.07 \pm 0.13$ \\
\hline
\end{tabular}

a $\operatorname{Mean} \pm \operatorname{SD}(n=5)$.

$\mathbf{T}$, type strain.

Table 4. Biochemical characteristics of Trichosporon domesticum and related species.

\begin{tabular}{|c|c|c|c|c|}
\hline $\begin{array}{l}\text { Assimilation of carbon } \\
\text { compounds }\end{array}$ & $\begin{array}{l}\text { T. domesticum } \\
{\mathrm{M} 9401^{\mathrm{T}}}\end{array}$ & $\begin{array}{l}\text { T. montevideense } \\
\text { CBS } 6721^{\mathrm{T}}\end{array}$ & $\begin{array}{l}T . \text { montevideense } \\
\text { CBS } 8261\end{array}$ & $\begin{array}{l}\text { T. brassicae } \\
\text { CBS } 6382^{\mathrm{T}}\end{array}$ \\
\hline L-Sorbose & + & - & - & + \\
\hline Cellobiose & + & + & + & - \\
\hline Lactose & + & + & + & - \\
\hline Melezitose & + & + & + & - \\
\hline D-Arabinose & - & $+(w)$ & $+(w)$ & - \\
\hline Ribitol & - & $+(w)$ & $+(w)$ & - \\
\hline Dulcitol & - & + & + & - \\
\hline Salicin & $+(w)$ & + & + & - \\
\hline$\alpha$-Methyl-D-glucoside & + & + & + & - \\
\hline
\end{tabular}

+ , positive; - , negative; $\mathbf{w}$, weakly positive. ${ }^{\mathrm{T}}$, type strain.

from $T$. brassicae by its ability to assimilate cellobiose, lactose, melezitose, salicin and $\alpha$-methyl-D-glucoside (Table 4). T. domesticum was isolated from the SHP patient's house, but it is not known whether this species is the causative agent of the disease or not, because we do not yet have any evidence of inhalation challenge with this species. Our new species, T. domesticum, has been deposited as JCM 9580 in The Japan Collection of Microorganisms, The Institute of Physical and Chemical Research (RIKEN) in Wako, Saitama, Japan.

We thank Prof. J. Sugiyama, Institute of Molecular and Cellular Biosciences, The University of Tokyo, for his help in the preparation of the Latin diagnosis, and Dr. T. Nakase, The Japan Collection of Microorganisms, The Institute of Physical and Chemical Research (RIKEN) for depositing the culture.

\section{REFERENCES}

1) Adnan, S., Li, N., Miura, H., Hashimoto, Y., Yamamoto, H., and Ezaki, T., Covalently immobilized DNA plate for luminometric DNA-DNA hybridization to identify viridans streptococci in under 2 hours. FEMS Microbiol. Lett., 106, 139-142 (1993).

2) Ando, M., Arima, K., Yoneda, R., and Tamura, M., Japanese summer-type hypersensitivity pneumonitis. Am. Rev. Respir. Dis., 144, 765-769 (1991).

3) Ando, M., Sakata, T., Yoshida, K., Yamasaki, H., Araki, S., Onoue, K., and Shinoda, T., Serotype-related antigen of Trichosporon cutaneum in the induction of summer-type hypersensitivity pneumonitis: Correlation between serotype of inhalation challenge-positive antigen and that of 
the isolates from patients' homes. J. Allergy Clin. Immunol., 85, 36-44 (1990).

4) Aulakh, H. S., Straus, S. E., and Kwon-Chung, K. J., Genetic relatedness of Filobasidiella neoformans (Cryptococcus neoformans) and Filobasidiella bacillispora (Cryptococcus bacillisporus) as determined by deoxyribonucleic acid base composition and sequence homology studies. Int. J. Syst. Bacteriol., 31, 97-103 (1981).

5) Guého, E., Improvisi, R., de Hoog, G. S., and Dupont, B., Trichosporon on humans: A practical account. Mycoses, 37, 3-10 (1994).

6) Guého, E., Smith, M. Th., de Hoog, G. S., Billon-Grand, G., Christen, R., and Batenburg-van der Vegte, W. H., Contributions to a revision of the genus Trichosporon. Antonie van Leeuwenhoek, 61, 289-316 (1992).

7) Kreger-van Rij, N. J. W., The species. In The Yeasts: A Taxonomic Study, 3rd ed., ed. by Kreger-van Rij, N. J. W., Elsevier Science Publishers B. V., Amsterdam (1984), p. 16.

8) Kreger-van Rij, N. J. W., Genus 16. Trichosporon Behrend. In The Yeasts: A Taxonomic Study, 3rd ed., ed. by Kreger-van Rij, N. J. W., Elsevier Science Publishers B. V., Amsterdam (1984), p. 933-962.

9) Kurtzman, C. P., Prediction of biological relatedness among yeasts from comparisons of nuclear DNA complementarity. Stud. Mycol., 30, 459-468 (1987).

10) Kwon-Chung, K. J., Kozel, T. R., Edman, J. C., Polacheck, I., Ellis, D., Shinoda, T., and Dromer, F., Recent advances in biology and immunology of Cryptococcus neoformans. J. Med. Vet. Mycol., 30 (Suppl. 1), 133-142 (1992).

11) Lachance, M. A., Simple method for determination of deoxyribonucleic acid relatedness by thermal elution in hydroxyapatite microcolumns. Int. J. Syst. Bacteriol., 30, 433-436 (1980).

12) Martini, A. V. and Kurtzman, C. P., Deoxyribonucleic acid relatedness among species of the genus Saccharomyces sensu stricto. Int. J. Syst. Bacteriol., 35, 508-511 (1985).

13) Martini, A. V., Martini, A., and Cardinali, G., Electrophoretic karyotyping as a taxonomic tool in the genus Saccharomyces. Antonie van Leeuwenhoek, 63, 145-156 (1993).

14) Mizobe, T., Yamasaki, H., Doi, K., Ando, M., and Onoue, K., Analysis of serotype-specific antibodies to Trichosporon cutaneum type I and II in patients with summer-type hypersensitivity pneumonitis with monoclonal antibodies to serotype-related polysaccharide antigens. J. Clin. Microbiol., 31, 1949-1951 (1993).

15) Restrepo, B. I. and Barbour, A. G., Cloning of $18 \mathrm{~S}$ and $25 \mathrm{~S}$ rDNAs from the pathogenic fungus Cryptococcus neoformans. J. Bacteriol., 171, 5596-5600 (1989).

16) Shimazu, K., Ando, M., Sakata, T., Yoshida, K., and Araki, S., Hypersensitivity pneumonitis induced by Trichosporon cutaneum. Am. Rev. Respir. Dis., 130, 407-411 (1984).

17) Sugita, T., Nishikawa, A., and Shinoda, T., DNA relatedness among the three varieties of Cryptococcus albidus. J. Gen. Appl. Microbiol., 38, 83-86 (1992).

18) Sugita, T., Nishikawa, A., and Shinoda, T., Reclassification of Trichosporon cutaneum by DNA relatedness by using the spectrophotometric method and the chemiluminometric method. J. Gen. Appl. Microbiol., 40, 397-408 (1994).

19) Van der Walt, J. P. and Yarrow, D., Methods for the isolation, maintenance, classification and identification of yeasts. In The Yeasts, A Taxonomic Study, 3rd ed., ed. by Kreger-van Rij, N. J. W., Elsevier Science Publishers B. V., Amsterdam (1984), p. 45-105.

20) Yamada, Y. and Kondo, K., Coenzyme Q system in the classification of the yeast genera Rhodotorula and Cryptococcus, and the yeast like genera Sporobolomyces and Rhodosporidium. J. Gen. Appl. Microbiol., 19, 59-77 (1973).

21) Yamasaki, H., Ando, M., Sakata, T., Araki, S., and Onoue, K., Importance of serotype-related antigen in the induction of experimental hypersensitivity pneumonitis by Trichosporon cutaneum in rabbits. Am. Rev. Respir. Dis., 141, 734-742 (1990).

22) Yoshida, K., Ando, M., Sakata, T., and Araki, S., Environmental mycological studies on the causative agent of summer-type hypersensitivity pneumonitis. J. Allergy Clin. Immunol., 81, 475483 (1988). 